\title{
Updated estimates of carbon accumulation rates in coastal marsh sediments
}

\author{
X. Ouyang ${ }^{1,2}$ and S. Y. Lee ${ }^{1}$ \\ ${ }^{1}$ Australian Rivers Institute-Coast and Estuaries and School of Environment, Griffith University Gold Coast campus, \\ Southport Q1d 4222, Australia \\ ${ }^{2}$ Beijing Zhongqi Anxin Environmental Science \& Technology Co., Ltd., Beijing 100053, China
}

Correspondence to: X. Ouyang (xiaoguang.ouyang@griffithuni.edu.au)

Received: 31 October 2013 - Published in Biogeosciences Discuss.: 6 December 2013

Revised: 7 July 2014 - Accepted: 25 July 2014 - Published: 19 September 2014

\begin{abstract}
Studies on carbon stock in salt marsh sediments have increased since the review by Chmura et al. (2003). However, uncertainties exist in estimating global carbon storage in these vulnerable coastal habitats, thus hindering the assessment of their importance. Combining direct data and indirect estimation, this study compiled studies involving 143 sites across the Southern and Northern hemispheres, and provides an updated estimate of the global average carbon accumulation rate (CAR) at $244.7 \mathrm{~g} \mathrm{C} \mathrm{m}^{-2} \mathrm{yr}^{-1}$ in salt marsh sediments. Based on region-specific CAR and estimates of salt marsh area in various geographic regions between $40^{\circ} \mathrm{S}$ to $69.7^{\circ} \mathrm{N}$, total CAR in global salt marsh sediments is estimated at $\sim 10.2 \mathrm{Tg} \mathrm{C} \mathrm{yr}^{-1}$. Latitude, tidal range and elevation appear to be important drivers for CAR of salt marsh sediments, with considerable variation among different biogeographic regions. The data indicate that while the capacity for carbon sequestration by salt marsh sediments ranked the first amongst coastal wetland and forested terrestrial ecosystems, their carbon budget was the smallest due to their limited and declining global areal extent. However, some uncertainties remain for our global estimate owing to limited data availability.
\end{abstract}

\section{Introduction}

Salt marshes are intertidal vegetated wetland ecosystems, dominant on protected shorelines and on the edge of estuaries in a range of climatic conditions, from sub-arctic to tropical, while most extensive in temperate latitudes (Mitsch et al., 1994; Butler and Weis, 2009; Laffoley and Grims- ditch, 2009). The combination of characteristic vegetation, geomorphology and habitat conditions of salt marshes provide essential ecosystem goods and services, including biogeochemical cycling and transportation of nutrients, habitat or food for coastal biota, shield and protecting coastal areas from storms and floods, water filtration, recreation and cultural benefits. However, salt marshes also critically suffer from losses due to dredging, filling, draining, construction and are particularly threatened by sea level rise as a result of "coastal squeeze" (Doody, 2004; Polunin, 2008; Gedan et al., 2009; Koch et al., 2009; Craft et al., 2008).

Salt marshes appear to be highly efficient in carbon burial, but studies on global carbon accumulation of salt marshes lag behind other coastal ecosystems. First, data on salt marsh extent and carbon stock are patchy. A reliable estimate of global salt marsh extent is lacking, and large areas of salt marsh have never been mapped. Existing studies of carbon stock on salt marshes tend to focus on specific sites and lack a broader global perspective (Callaway et al., 2012). Chmura et al. (2003) provided an extensive estimate of global carbon sequestration of salt marshes, although their study still did not cover the complete latitudinal range of salt marsh occurrence, but only from $22.4^{\circ} \mathrm{S}$ to $55.5^{\circ} \mathrm{N}$. Second, carbon sequestration by mangroves and seagrasses has been analyzed with specific hypotheses in mind, such as the existence of clear latitudinal gradients (McLeod et al., 2011), while such an approach has rarely been attempted for salt marshes. The lack of a comprehensive global view of carbon accumulation and storage in salt marshes contributes to this deficiency. Considerable studies have investigated carbon accumulation of salt marshes in different sites, including elevation gradients 
from low to mid- or high marsh (Callaway et al., 1996; Connor et al., 2001; Elsey-Quirk et al., 2011; Callaway et al., 2012; Schuerch et al., 2012; Adams et al., 2012), but these studies focused on carbon density, organic matter and sediment accretion and no direct estimates have been reached concerning carbon accumulation capacity. Finally, how sediment carbon accumulation may respond to tidal range and species occurrence has been studied individually in specific sites and for various genera of salt marshes (Rothman and Bouchard, 2007; Zhou et al., 2007; Mahaney et al., 2008), but a global consideration of pattern is still lacking. Even though salt marshes have been intensively investigated for more than fifty years, the global capacity for carbon sequestration by salt marshes is yet to be assessed. A global analysis covering the full range of salt marsh distribution will provide an opportunity to identify the role of these hotspots in climate change impact in terms of carbon storage and to inform future global conservation efforts.

Carbon sinks in salt marshes generally consist of aboveground biomass, belowground biomass and soils. Globally, it is recognized that soils contain the largest quantity of carbon in a range of ecosystems and two thirds of carbon is in the form of soil organic matter (Batjes, 1996). Likewise, the largest carbon stock of salt marshes is soil organic carbon (Murray et al., 2011), which is influenced by the carbon accumulation rate (CAR). Estimating global salt marsh CAR is significant to understanding carbon sequestration by salt marsh sediments.

CAR is calculated as the product of sediment accretion rate (SAR) and average carbon density of the soil (Connor et al., 2001; Ford et al., 2012). To date, studies on CAR have been restricted in geographic extent, whereas comprehensive data are available on SAR and soil carbon density in salt mash ecosystems. Combining data of the two parameters will establish a global CAR inventory of salt marshes.

This paper aims to refine the global CAR inventory of salt marshes, extending the earlier review by Chmura et al. (2003) on the basis of recent published studies on specific regions, and to explore regional differences (including latitudinal and biogeographic differences) in CAR, as well as the nexus of CAR with key environmental and biotic drivers. The updated database may then be used to generate an improved estimate of the global carbon storage in salt marsh sediments.

\section{Method}

\subsection{Data sources and collation}

We searched for relevant studies using the databases Science Citation Index Expanded, Conference Proceedings Citation Index-Science and Book Citation Index-Science within ISI Web of Science (Thomson Reuters), using the Boolean search statement: topic $=\left(\right.$ salt $^{*}$ marsh* or salt marsh $)$ AND (carbon* or sediment* or soil). This search generated 4939 studies, including 174 reviews, 414 proceeding papers and 56 book chapters, and the rest were journal articles.

Data were then selected according to the following principles:

(a) Some studies recorded CAR in terms of sequestered $\mathrm{CO}_{2}$. The values were considered as CAR, because salt marshes produce negligible methane (Connor et al., 2001; Callaway et al., 2012).

(b) As far as the few studies regarding accumulation rate of organic matter were concerned, carbon values were calculated according to the formula of Craft et al. (1991).

(c) SAR estimates may involve a variety of tracers and profiles of tracers (Ouyang et al., 2013), including longterm profiles of ${ }^{137} \mathrm{Cs},{ }^{210} \mathrm{~Pb}$ and short-term marker horizons. Then CAR was obtained by multiplying SAR and soil carbon density. As SAR could be variable over small spatial scales, CAR estimation is expectedly influenced by data availability. Despite the absence of method description in $9 \%$ of the studies, most $(64 \%)$ employed radionuclide (i.e., ${ }^{137} \mathrm{Cs},{ }^{210} \mathrm{~Pb}$ markers) to measure SAR, while another $27 \%$ of studies used marker horizons. CAR derived from different methods for SAR measurement may generate biases in comparison to CAR but those data potentially affected are highlighted in our results.

(d) According to the current classification of salt marshes (Mold, 1974; Chmura et al., 2003), the 143 sites were geographically divided into eight groups (Fig. 1), namely, tropical W Atlantic, N Europe, Mediterranean, NE Pacific, NW Atlantic, Arctic, Australasia and SinoJapan. Also, there is a phytobiogeographic division based on the dominant halophyte genera at the 143 sites, with Distichlis, Spartina, Phragmites, Juncus and Halimione being the dominant taxa.

Following the above rules, we examined individual studies to confirm the validity of the data. Studies were excluded if they were based on model simulation. This process filtered the studies down to 50, including 37 studies in which SAR and soil carbon density data were used to calculate CAR, while the remaining 13 studies directly reported CAR. In addition, among the 50 studies, 47 were based on sediment samples of short cores $(<1 \mathrm{~m})$, whereas only 3 studies sampled using deeper cores. Overall, the studies covered a latitudinal range from $40^{\circ} \mathrm{S}$ to $69.7^{\circ} \mathrm{N}$ (Table 1 ).

The area of salt marshes by specific sites and regions is well described in the literature (Dijkema, 1987; O'Callaghan, 1990; Yang and Chen, 1995; Hanson and Calkins, 1996; Saint-Laurent et al., 1996; Lawrence et al., 2012), while reports of estimates of the global area are scarce. In this study, data of published studies were compiled to provide an estimate of the present global extent of salt marshes (Table 2). The global total carbon (C) stock in salt marshes was then 


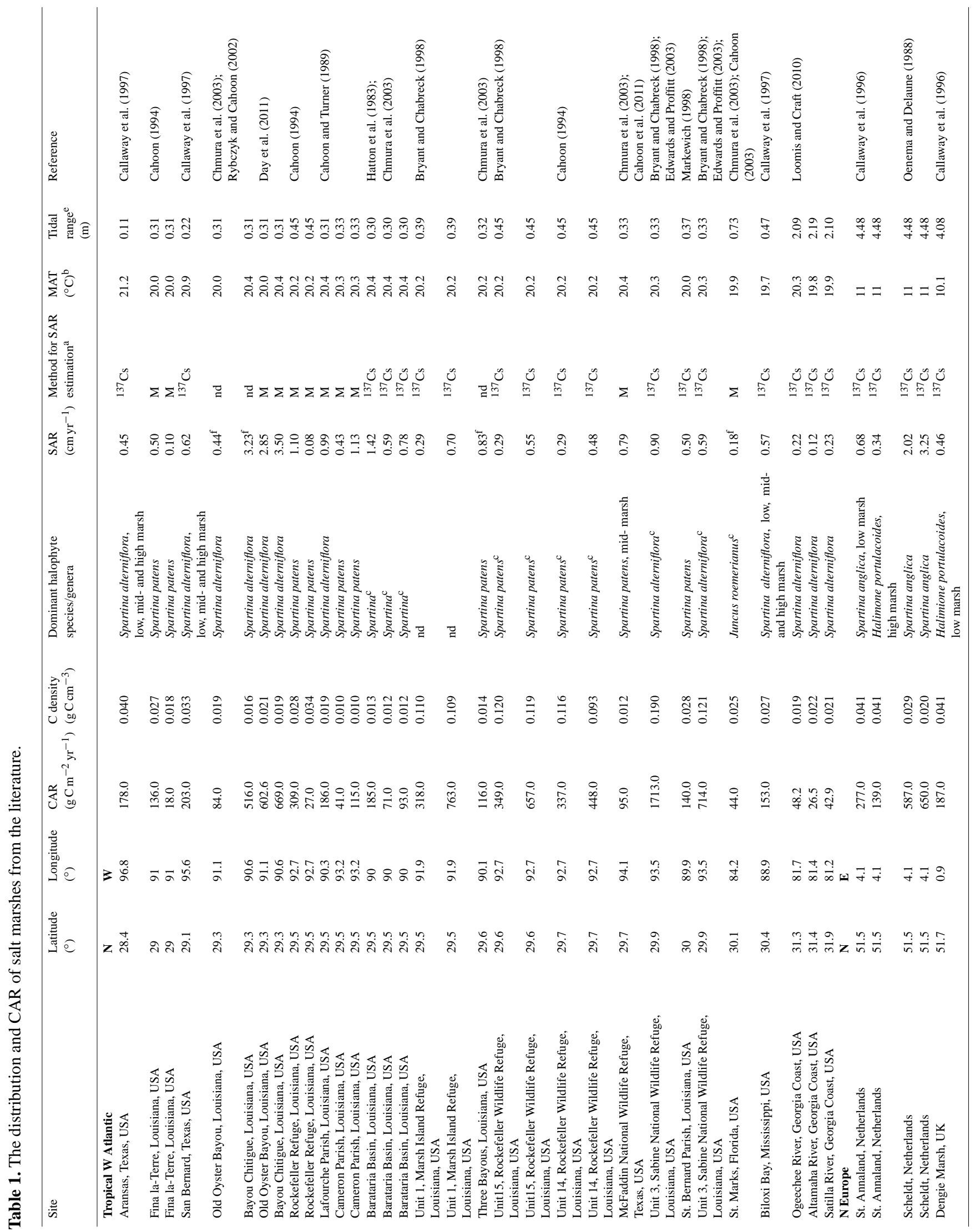




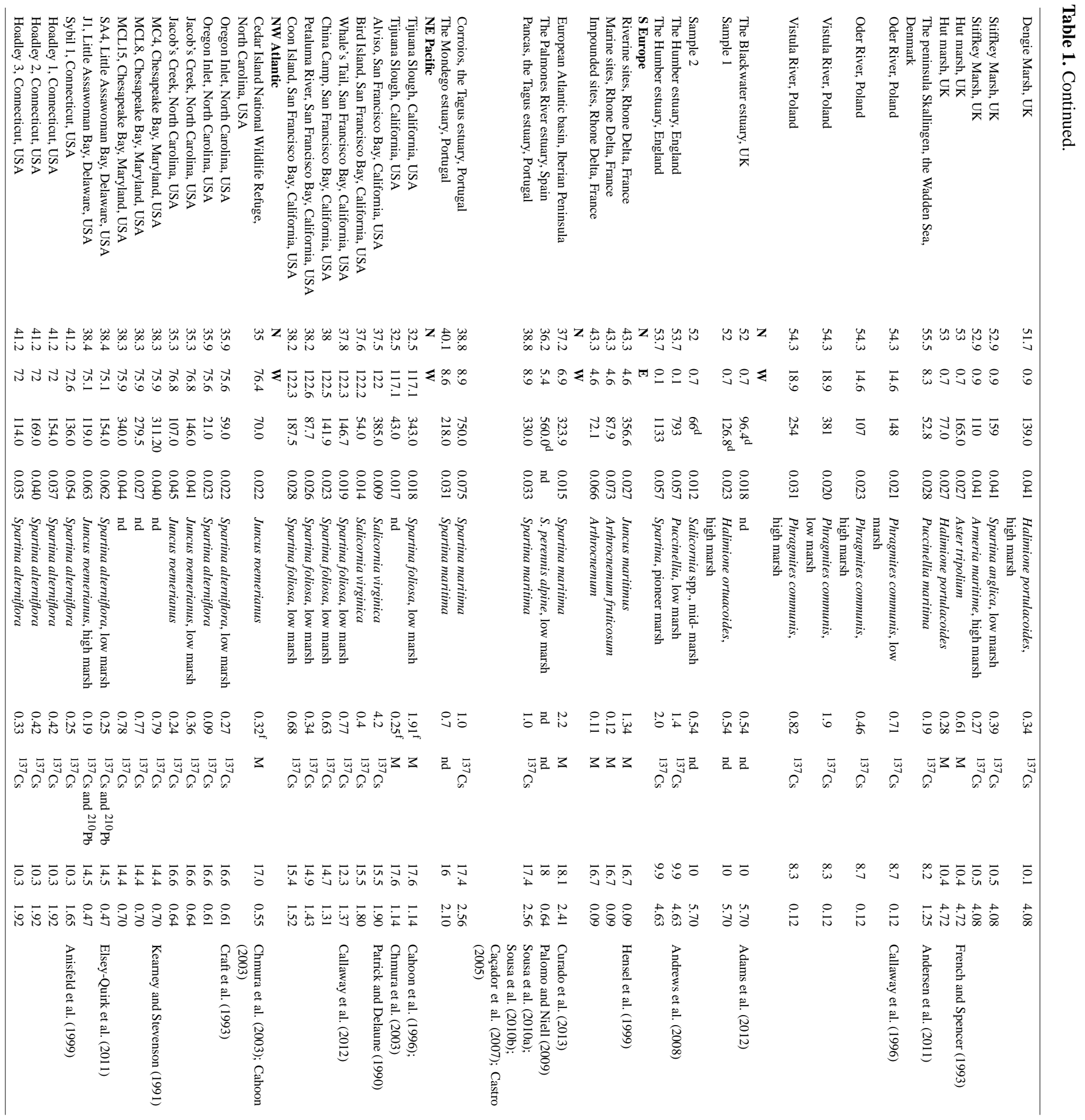




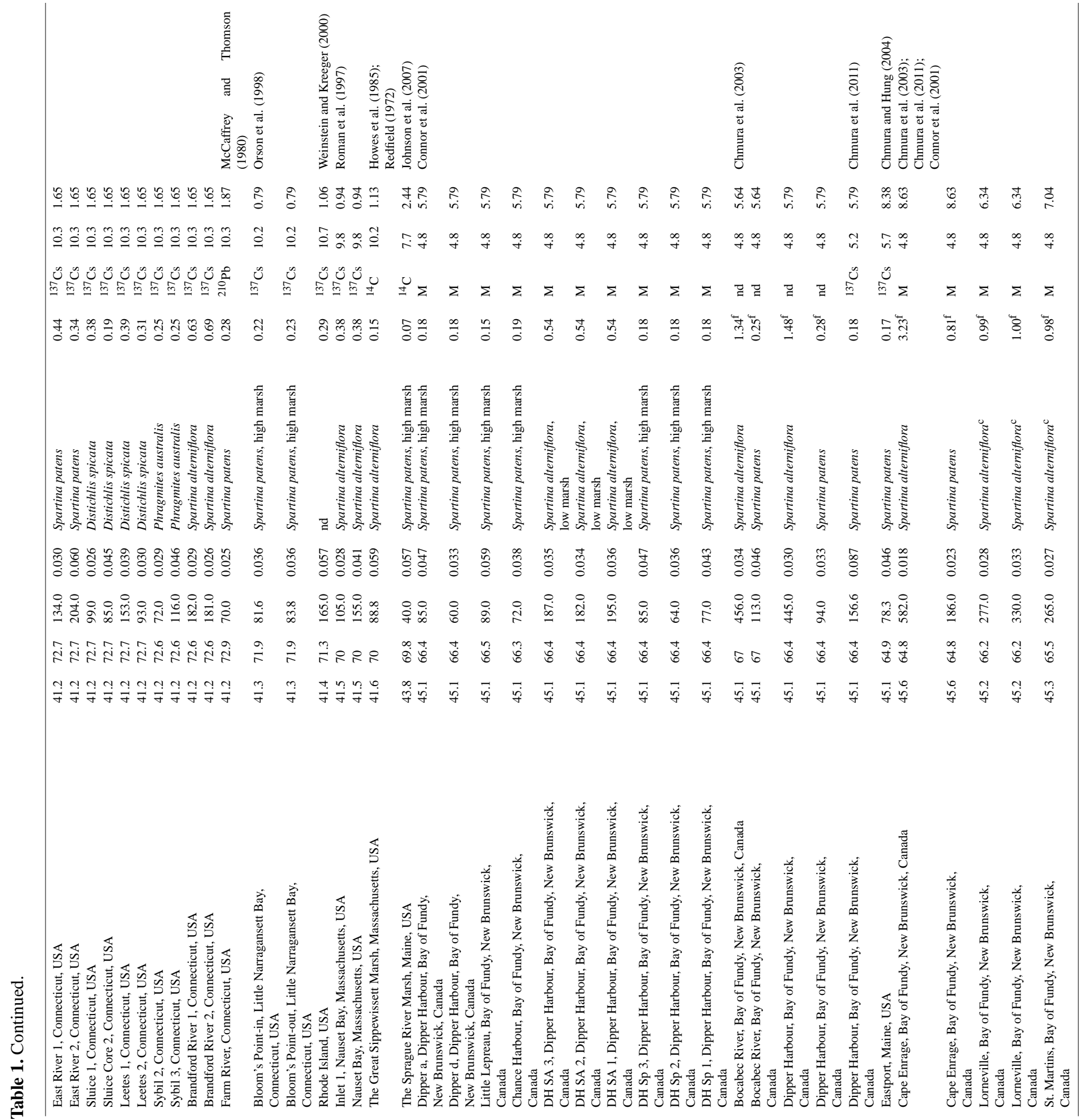




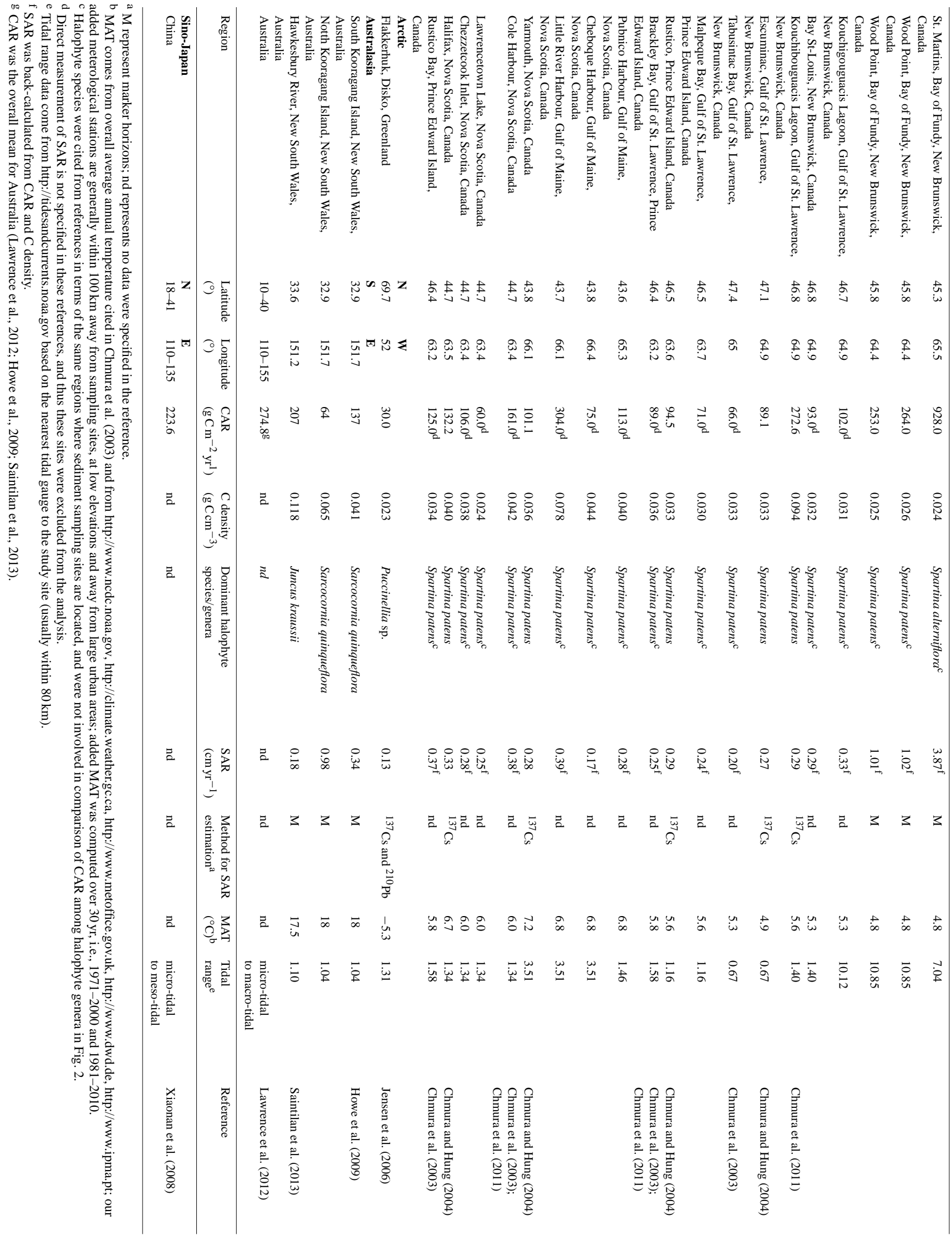




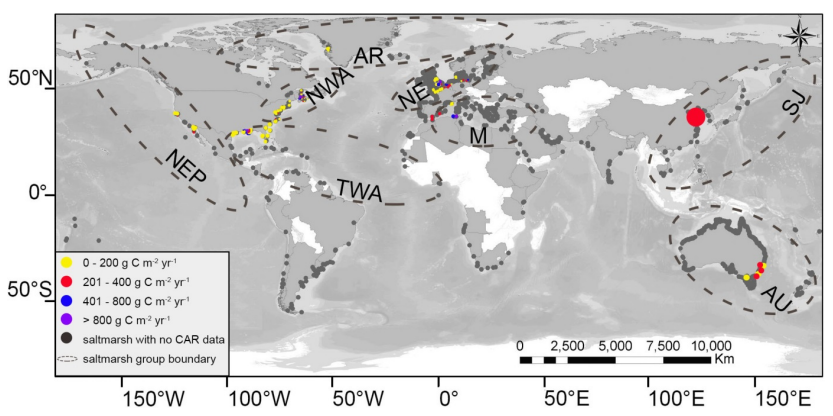

Figure 1. Groupings and CAR of global salt marsh ecosystems. The eight groups span latitudes from $40^{\circ} \mathrm{S}$ to $69.7^{\circ} \mathrm{N}$, colonizing the coasts and estuaries of the Pacific, Atlantic, Indian and Arctic oceans. The background graph indicating sites of salt marshes is based on Mold (1974) and Murray et al. (2011). While significant salt marsh occurrences are present in South America, insufficient data is available for inclusion in this analysis since there are no pertinent references. Color dots are used to account for CAR levels of individual sites that were indicated in Table 1 from 50 studies, whereas dull color dots represent sites without CAR data. There are not substantial data for the Sino-Japan region, as such a big circle is used to represent the average CAR of this region. Only locations with published data allowing calculation of CAR are represented for clarity. NEP - NE Pacific; TWA - tropical W Atlantic; NWA NW Atlantic; AR - Arctic; NE - N Europe; M - Mediterranean; SJ - Sino-Japan; AU - Australasia.

estimated by multiplying region-specific CAR and the respective regional areal extent of salt marshes. Area of salt marsh in these sub-groups was estimated from Coultas and Hsieh (1997). Soil CAR of Europe and Scandinavia was calculated by combining all the CAR data of northern Europe and the northern Mediterranean. CAR of northern Africa (Tunisia and Morocco) adopted that of the closest region, i.e., the northern Mediterranean group, as no CAR values specific to this region are available. CAR of arid salt marshes may differ from other Mediterranean sites so some errors may result from the use of this value. There is also no available CAR data of southern Africa, despite many reports of Spartina in southern African salt marshes, e.g., Adams and Bate (1995); Pierce (1983); Ranwell (1967). The value in Fig. 2 for Spartina was used to approximate CAR of this region. Since the areas of salt marsh in southern and northern Africa are small, these approximations have relatively little influence on the estimation of total CAR in global salt marsh sediments.

Despite the large areal extents of salt marshes, few data on CAR are available for the Australasia and Sino-Japan regions. The contributions from these regions are therefore extrapolations from a small number of studies, which may not be representative of the mean values applicable to the regions. While these still represent the best available data, our overall global CAR value should be interpreted with some caution.

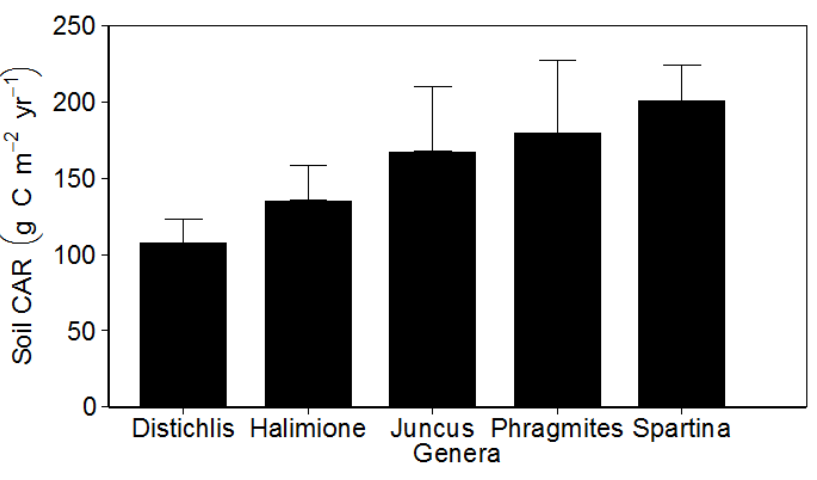

Figure 2. Comparison of CAR among halophyte genera from data in the collated references. A non-parametric post hoc pairwise test was run following Kruskal-Wallis rank sum test to test which genera are different from the others. Spartina marshes have significantly higher CAR but there are no significant differences in CAR among the other four groups (Kruskal-Wallis test, $P>0.05$ ).

Table 2. Reported area of salt marshes.

\begin{tabular}{lcl}
\hline Region & Area $\left(\mathrm{km}^{2}\right)$ & Ref. \\
\hline Australia & 13765 & Lawrence et al. (2012) \\
China & 5734 & Shi-lun and Ji-yu (1995) \\
America & 19265 & Field et al. (1991) \\
Europe and Scandinavia & 2302 & $\begin{array}{l}\text { Dijkema (1987); } \\
\text { Saint-Laurent (1996) } \\
\text { Canada }\end{array}$ \\
Northern Africa & 328 & Hanson and Calkins (1996); \\
Southern Africa & 93 & Wetland International Inventory \\
& 170 & O'Callaghan (1990) \\
\hline Total & 41657 & \\
\hline
\end{tabular}

We explored the potential range of the global CAR value following the "uncertainty propagation" approach of Donato et al. (2011). See Supplementary information for details of the method.

\subsection{Data analysis}

Analyses were conducted using SPSS 21 (SPSS Inc., Chicago, IL, USA) and R version 3.0.2 (R Core Team, 2013). Deviations are reported as the standard error (SE). For statistical comparisons, data were tested for normality with the Kolmogorov-Smirnov test and for homogeneity of variance with the Levene's test $(\alpha=0.05)$. When homogeneity of variance between groups was violated, data were transformed $\left(\ln (x), 1 / x\right.$, or $\left.x^{1 / 2}\right)$ to satisfy the assumption. Box plots were used to describe latitudinal distribution of CAR data. A paired-sample $t$ test was used to compare the paired CAR from marshes with different elevations at the same site. In the case of heterogeneity of variances, Kruskal-Wallis rank sum test was applied to compare more than two means and followed by non-parametric post hoc pairwise test where there was a significant treatment effect. 
Table 3. Comparison of CAR among salt marsh geographic groups. Australasia, Sino-Japan and Arctic are excluded from the analysis due to low number of sites. Southern Europe includes the northern Mediterranean sites and Portugal. There are no significant differences in the mean CAR value among the five groups for which sufficient data are available for comparison (Kruskal-Wallis test, $P>0.05)$.

\begin{tabular}{llc}
\hline Groups & $\begin{array}{l}\text { Number } \\
\text { of sites }\end{array}$ & $\begin{array}{c}\text { Soil CAR, } \mathrm{g} \mathrm{C} \mathrm{m}^{-2} \mathrm{yr}^{-1} \\
(\mathrm{Mean} \pm \mathrm{SE})\end{array}$ \\
\hline Tropical W Atlantic & 32 & $293.7 \pm 60.9$ \\
N Europe & 23 & $315.2 \pm 62.9$ \\
S Europe & 7 & $305.5 \pm 86.0$ \\
NE Pacific & 8 & $173.6 \pm 45.1$ \\
NW Atlantic & 64 & $172.2 \pm 18.1$ \\
\hline
\end{tabular}

Stepwise multiple regression was used to determine which of the independent variables, viz., tidal range, latitude, halophyte genera and MAT, accounted for most of the variation in CAR. The five major genera were included as a categorical variable with four levels, while other genera were excluded owing to few available data. Each level has two values, namely, 0 and 1 . The categorical variable, serving as a qualitative variable, was included as a block with the default "Enter" method, whereas tidal range and latitude were included as another block with the default "Stepwise" method in the multiple regression model. A regression tree was created and structured in a hierarchical fashion to determine the influences of independent variables (i.e., latitude, halophyte genera, tidal range and MAT) on the distribution of CAR values.

\section{Results and discussion}

\subsection{Regional difference in carbon accumulation rate}

In order to assess the regional difference in carbon sequestration by salt marshes, soil CAR was calculated for the five salt marsh groups for which sufficient comparative data are available (Table 3), the five dominant halophyte genera (Fig. 2), and for latitudinal intervals of $10^{\circ}$ from $28.4^{\circ} \mathrm{N}$ to $69.7^{\circ} \mathrm{N}$. Region-specific CAR and area were combined to produce a global CAR of salt marshes. Globally, mean CAR in salt marsh sediment is $244.7 \pm 26.1 \mathrm{~g} \mathrm{C} \mathrm{m}^{-2} \mathrm{yr}^{-1}$ (Table 4).

Compared to previous studies, our results show both differences and common features. First, the average CAR of our study is higher than those from earlier reports, averaged $151 \mathrm{~g} \mathrm{C} \mathrm{m}^{-2} \mathrm{yr}^{-1}$ (Chmura et al., 2003; Duarte et al., 2005). Our estimate has revised the former estimates upward by roughly $60 \%$. The difference may relate to the fact that the earlier reports (1) have smaller latitudinal ranges (from $22.4^{\circ} \mathrm{S}$ to $55.5^{\circ} \mathrm{N}$ ); (2) suffer from the lack of data from significant regions, including the Asia-Pacific, Arctic and Australasia; or (3) used a simplistic method for up-scaling CAR

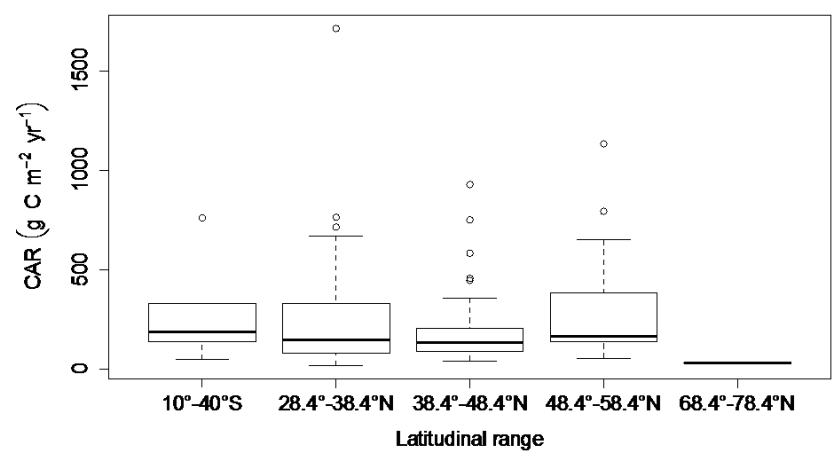

Figure 3. Latitudinal pattern of CAR for global salt marshes. The box-whisker plots of CAR reflect a clear pattern at latitudinal range $10-40^{\circ} \mathrm{S}, 28.4-38.4^{\circ} \mathrm{N}, 38.4-48.4^{\circ} \mathrm{N}, 48.4-58.4^{\circ} \mathrm{N}$, and $68.4-78.4^{\circ} \mathrm{N}$, with the highest value in the $48.4-58.4^{\circ} \mathrm{N}$ (mean $\mathrm{CAR}=315.2 \mathrm{~g} \mathrm{C} \mathrm{m}^{-2} \mathrm{yr}^{-1}$ ), while the lowest value occurs at highlatitudinal $68.4-78.4^{\circ} \mathrm{N}$ (mean $\mathrm{CAR}=30 \mathrm{~g} \mathrm{C} \mathrm{m}^{-2} \mathrm{yr}^{-1}$ ). No data is available for the $58.4-68.4^{\circ} \mathrm{N}$ range and is not presented in the plot. The bottom, middle and top of each box indicates the 25 th, 50th (median) and 75th percentiles, respectively. Around $95 \%$ of the data are expected to lie between whiskers. The scattered points above the whiskers are outliers and the upper points are extreme outliers.

from individual sites to the global coverage, i.e., arithmetic means of individual CAR irrespective of regional salt marsh area.

The highest average accretion rate of soil carbon, i.e., $315.2 \mathrm{~g} \mathrm{C} \mathrm{m}^{-2} \mathrm{yr}^{-1}$, was recorded from the northern Mediterranean marshes dominated by Spartina spp. The largest carbon stock was in accordance with data of soil carbon stores in seagrass ecosystems, which was also found in Mediterranean meadows dominated by Posidonia oceanica (Fourqurean et al., 2012). However, the only recorded CAR of salt marsh soils in the Arctic is an order of magnitude lower $\left(30 \mathrm{~g} \mathrm{C} \mathrm{m}^{-2} \mathrm{yr}^{-1}\right)$ than those of all other regions (172.2 to $315.2 \mathrm{~g} \mathrm{C} \mathrm{m}^{-2} \mathrm{yr}^{-1}$ ). But the lack of data for this region makes generalization difficult. Furthermore, as shown in Fig. 2, among the five halophyte genera, Spartina demonstrated the highest capacity for soil carbon accumulation, with average CAR at $200.9 \mathrm{~g} \mathrm{C} \mathrm{m}^{-2} \mathrm{yr}^{-1}$, while average CAR of Distichlis $\left(107.5 \mathrm{~g} \mathrm{C} \mathrm{m}^{-2} \mathrm{yr}^{-1}\right)$ ranked the lowest. CAR of Spartina was significantly higher but there are no significant differences in CAR among other genera $(P>0.05)$. Nonetheless, there is significant latitudinal variation of CAR in salt marsh sediments $(P<0.001)$ (Fig. 3).

For exploring the drivers of CAR variation, the nexus of CAR with tidal range, latitude, MAT and the dominant halophyte genera was analyzed using multiple linear regressions. There is no significant impact of MAT $(P=0.567)$ or genera $(P=0.728)$ on CAR. Tidal range and latitude accounted for $51.7 \%$ and $29.6 \%$ of the variation in CAR $(P<0.05)$. In addition, regression tree analysis was applied to compare the impact of latitude, mean tidal range (MTR), MAT and 
Table 4. Estimation of global CAR using specific soil CAR for different regions. USA was divided into three sub-groups as per the division of salt marsh groups in Fig. 1.

\begin{tabular}{llll}
\hline Region & $\begin{array}{l}\text { Soil CAR, } \mathrm{g} \mathrm{C}^{-2} \mathrm{yr}^{-1} \\
(\mathrm{mean} \pm \mathrm{SE})\end{array}$ & $\begin{array}{l}\text { Area } \\
\left(\mathrm{km}^{2}\right)\end{array}$ & $\begin{array}{l}\text { Soil CAR, } \mathrm{Tg} \mathrm{f}^{-1} \\
(\mathrm{mean} \pm \mathrm{SE})\end{array}$ \\
\hline $\begin{array}{l}\text { Australia } \\
\text { China }\end{array}$ & 274.8 & 13765 & 3.78 \\
USA & 223.6 & 5734 & 1.28 \\
$\quad$ & & \\
$\quad$ Tropic W Atlantic region & $293.7 \pm 60.9$ & 8596 & $2.52 \pm 0.52$ \\
$\quad$ NW Atlantic region & $134.0 \pm 12.8$ & 2685 & $0.36 \pm 0.03$ \\
$\quad$ NE Pacific region & $173.6 \pm 45.1$ & 7984 & $1.39 \pm 0.36$ \\
Europe and Scandinavia & $312.4 \pm 50.6$ & 2302 & $0.72 \pm 0.12$ \\
Canada & $214.3 \pm 33.7$ & 328 & $0.07 \pm 0.01$ \\
Northern Africa & $305.5 \pm 86.0$ & 93 & $0.03 \pm 0.01$ \\
Southern Africa & $200.9 \pm 23.0$ & 170 & $0.03 \pm 0.004$ \\
Total & $244.7 \pm 26.1$ & 41657 & $10.2 \pm 1.1$ \\
\hline
\end{tabular}

dominated genera on CAR (Fig. 4). Latitude occupies the highest hierarchy and MTR constitutes the primary branches of the regression tree, while MAT is not an independent determinant of CAR.

These results suggest that carbon sequestration by salt marsh sediments is affected by multiple biogeochemical and biotic factors. Tidal range determines belowground carbon dynamics (root production, carbon burial) through influencing sediment aeration and porewater flow, also affecting sediment and organic matter import/export dynamics. Soil CAR for salt marshes was shown to be positively related to belowground biomass productivity and negatively related to organic matter decomposition (Elsey-Quirk et al., 2011; McLeod et al., 2011; Gonzalez-Alcaraz et al., 2012), which are the predominant biotic processes for carbon accumulation. Both processes are affected by tidal range.

For a given inundation depth, biomass productivity should be greatest in low tidal range environment (Schuerch et al., 2012). Where biomass productivity may be low (e.g., some Mediterranean marshes), retention of organic matter is usually high in these micro-tidal environments (Ibañez et al., 2000). Thus CAR could be higher in micro-tidal marshes. Further, tidal range may result in differences in the frequency of tidal flooding (Chmura et al., 2011), which alters the mode and rate of organic matter decomposition (Gonzalez-Alcaraz et al., 2012) and export generally in tidal wetlands (Saintilan et al., 2013; Lee, 1995), thereby influencing CAR. Marsh vegetation also influences carbon accumulation through litter input. A number of studies have revealed that different species of halophyte inhabiting salt marshes contributed different quality and quantities of litter to salt marsh sediments (Zhou et al., 2007; Mahaney et al., 2008). Soil microbe mediated decomposition also changes with litter species (Rothman and Bouchard, 2007). These factors combined would result in variation in the quality (e.g., stoichiometry and form of essential elements) as well as quantity (e.g., different pro-

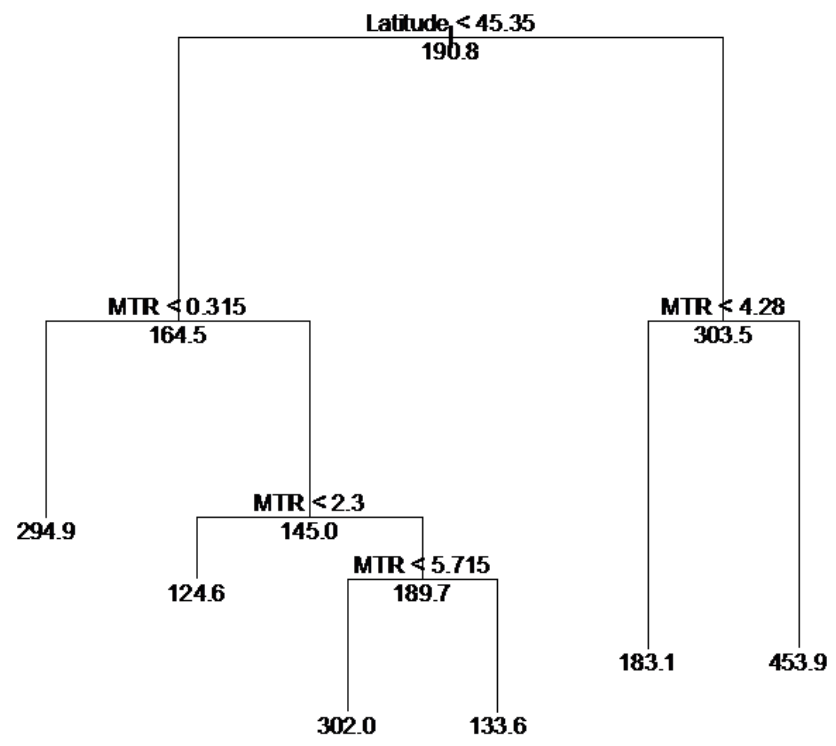

Figure 4. A regression tree for estimating CAR from latitude, mean tidal range and dominated genera. At each internal node, we asked the associated question, and go to the right child if the answer is "no", go to the left child if the answer is "yes". MTR denotes mean tidal range.

duction and turnover rates) of organic matter in salt marsh sediments.

Latitude is a proxy of drivers such as length of growing season, and sediment salinity may also vary with latitude due to differences in the balance between evaporation and rainfall. Significant latitudinal trend can therefore be expected for primary productivity. This study suggests that salt marsh CAR changes markedly with length of growing season. Generally, this study suggests CAR of salt marsh sediments peaks at mid-latitudes, between $\sim 48.5$ and $58.5^{\circ} \mathrm{N}$, and decreases towards the poles and the equator. This pattern corresponds with the general latitudinal pattern of salt 


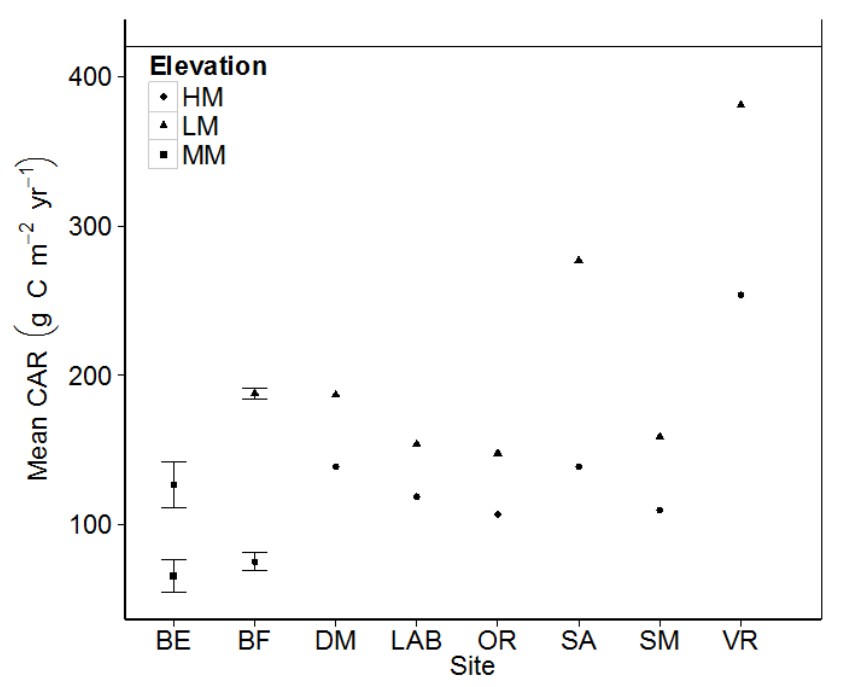

Figure 5. CAR of salt marshes in relation to habitat elevation from low marsh to mid- or high marsh. Different symbols for CAR of low, mid- and high-marsh locations from the same site were aligned vertically. BE - the Blackwater Estuary, UK; BF - the Bay of Fundy, New Brunswick, Canada; SM - Stiffkey Marsh, UK; DM - Dengie Marsh, UK; SA - St. Annaland, Netherlands; OR - Oder River, Poland; VR - Vistula River, Poland; LAB - Little Assawoman Bay, USA; HM - high marsh; MM - mid-marsh; LM - low marsh.

marsh development. Additionally, variations in salinity lead to difference in soil properties among coastal marshes, and soil bulk density was positively correlated with organic carbon concentrations and negatively correlated with salinity. Carbon accumulation was negatively correlated with salinity, attributed to impact of salinity on decomposition rate of organic matter (Loomis and Craft, 2010). Furthermore, temperature influences the underlying metabolic processes of carbon gain through photosynthesis and carbon loss through microbial and plant respiration. Moderate rises in temperature can give rise to salt marsh productivity in temperate latitudes, e.g., the pattern of increasing salt marsh macrophyte productivity with temperature (Kirwan et al., 2009) or decreasing productivity with latitude (Turner, 1976) in North American coastal marshes. However, rises in temperature may also result in metabolic changes, distribution shifts and decreased soil $\mathrm{C}$ density owing to increased decomposition rates (Chmura et al., 2003; McLeod et al., 2011). Thus, its positive effect on the primary productivity and negative effect on $\mathrm{C}$ decay may entrain the decrease of CAR from midlatitudes towards the equator or the poles.

\subsection{Variation of CAR with marsh elevation}

Soil CAR presents a clear declining trend from low marsh to high marsh across all locations with data available for comparison (paired-sample $t$ test, $P<0.001$; Fig. 5). The variation of CAR with respect to elevation could be explained by its drivers. CAR is driven by three parameters, i.e., SAR, dry bulk density of the soil (DBD) and its organic carbon content, which is positively related to loss on ignition (LOI). Connor et al. (2001) reported that low-marsh sediments were characterized by higher soil bulk densities and lower LOI. According to Chmura and Hung (2004), SAR decreases with distance from the nearest creek, i.e., low marsh have higher SAR than high marsh, probably due to shorter inundation time and thus reduced sediment input. Oenema and Delaune (1988) developed a function describing the relationship between SAR and the distance of a marsh from the major creeks, showing that SAR of low marsh is higher than that of high marsh.

High-marsh sediments, however, are likely to have higher carbon content (Connor et al., 2001; Zhou et al., 2007). In addition, it was indicated that root productivity of salt marsh species was higher in low-inundation conditions than that in high-inundation conditions (Blum, 1993). The pattern of low marsh having higher CARs suggests that this increase in carbon content and root productivity is more than offset by the decrease in SAR and DBD while going landward. In our collated literature, CAR of mid-marsh was lower than high marsh. The reason for this lack of a clear-cut pattern from low to high marsh is unclear but differences in tidal inundation duration and flow dynamics between the mid- and highmarsh elevations are expected to be smaller than those between low and mid-elevations. And the highest root growth of some salt marsh species at an optimum elevation rather than at low and high marsh (Kirwan and Guntenspergen, 2012) may also facilitate the higher sediment carbon accumulation at mid-marsh than at high marsh.

\subsection{Global CAR in salt marsh sediments compared with other ecosystems}

Our global estimate of salt marsh carbon stocks is based on the area-weighted mean value of the 143 sites so that the high CAR of the northern Mediterranean does not unduly affect the global figure. The product of our mean regional CAR and the area of salt marshes for the respective reported regions estimates the global CAR of salt marsh sediments to be about 10.2 $\pm 1.1 \mathrm{TgC} \mathrm{yr}^{-1}$ (Table 5). Based on the uncertainty propagation method (see Supplementary information), the potential range of this value has been estimated to be between $0.9 \mathrm{TgC}^{-1}$ and $31.4 \mathrm{TgC} \mathrm{yr}^{-1}$. This range is significantly wider than that estimated for global mangrove $\mathrm{C}$ storage by Donato et al. (2011), where there is a fivefold difference between the lower and upper limits. The wide range can be attributed to the large differences in reported CAR, with the highest value about 20x the lowest value.

This estimate has a couple of important caveats. First, for some regions the CAR is based on small number of measurements/sites extrapolated to large areal extents (e.g., Australia and China). This will potentially cause significant errors to the regional estimate but also highlights the need to obtain more measurements incorporating the range of species and 
Table 5. Comparison of carbon accumulation in sediments and soils of salt marshes and other ecosystems. ND - no data.

\begin{tabular}{|c|c|c|c|c|c|}
\hline Ecosystems & $\begin{array}{l}\text { Soil CAR, } \\
\mathrm{g} \mathrm{C} \mathrm{m}^{-2} \mathrm{yr}^{-1} \\
(\text { mean } \pm \mathrm{SE})\end{array}$ & $\begin{array}{l}\text { Number of } \\
\text { studies/ } \\
\text { sites }\end{array}$ & $\begin{array}{l}\text { Global area, } \\
\mathrm{km}^{2} \\
(\text { mean } \pm \mathrm{SE})\end{array}$ & 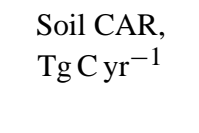 & Reference \\
\hline \multicolumn{6}{|c|}{ Coastal ecosystems } \\
\hline Salt marshes & $242.2 \pm 25.9$ & $50 / 143$ & 41657 & $10.1 \pm 1.1$ & This study \\
\hline Mangroves & $226 \pm 39$ & $13 / 34$ & $\begin{array}{l}137760 \text { to } \\
152361\end{array}$ & $\begin{array}{l}31.1 \pm 5.4 \text { to } \\
34.4 \pm 5.9\end{array}$ & $\begin{array}{l}\text { Giri et al. (2011); Chmura et al. (2003); } \\
\text { Bird et al. (2007); Lovelock et al. (2010); } \\
\text { Sanders et al. (2010); Spalding et al. (2010) }\end{array}$ \\
\hline Seagrasses & $138 \pm 38$ & $\mathrm{ND} / 123$ & $\begin{array}{l}300000 \text { to } \\
600000\end{array}$ & $\begin{array}{l}41.4 \pm 11.4 \text { to } \\
82.8 \pm 22.8\end{array}$ & $\begin{array}{l}\text { Duarte et al. (2005); Kennedy et al. (2010); } \\
\text { Fourqurean et al. (2012) }\end{array}$ \\
\hline \multicolumn{6}{|c|}{ Terrestrial forest ecosystems } \\
\hline Temperate & $5.1 \pm 1.0$ & 18/ND & 10400000 & $53 \pm 10.4$ & Schlesinger and Bernhardt (2013) \\
\hline Boreal & $4.6 \pm 2.1$ & $5 / \mathrm{ND}$ & 13700000 & $63 \pm 28.8$ & Zehetner (2010) \\
\hline Tropical & $4.0 \pm 0.5$ & $15 / \mathrm{ND}$ & 19622846 & $78.5 \pm 9.8$ & $\begin{array}{l}\text { Asner et al. (2009); } \\
\text { Schlesinger and Bernhardt (2013) }\end{array}$ \\
\hline
\end{tabular}

environmental conditions typical of the study regions. Second, a small number of regions have no published CAR data at all and the current regional estimate was obtained using CAR from nearby regions or conspecific marshes, multiplied by the known area of salt marsh (e.g., northern Africa). Consequently, while we attempt to provide an updated global CAR value based on new data, there are still considerable data gaps associated with particular regions that would invite future research to further refine our estimates.

Our estimate of global total sediment CAR in salt marshes is lower than both its neighboring coastal mangrove and seagrass ecosystems $\left(31.1 \pm 5.48\right.$ to $\left.82.8 \pm 22.8 \mathrm{Tg} \mathrm{C} \mathrm{yr}^{-1}\right)$, and the upland terrestrial forest ecosystems $(53 \pm 10.4$ to $78.5 \pm 9.88 \mathrm{TgC}^{-1} \mathrm{yr}^{-1}$. As far as sediment CAR is concerned, our area-specific salt marsh CAR ranks the highest (Fig. 6) but the overall accumulation rate is reduced because of the limited areal extent of this habitat. The high capacity of carbon sequestration in salt marsh sediments can be attributed to oxygen-depleted sediment conditions reducing mineralization rate, continual sediment deposition/burial, and the combined high primary production but low export/consumption rates, which facilitate accumulation of organic matter (Hussein et al., 2004; Loomis and Craft, 2010; Callaway et al., 2012; Keller et al., 2012).

Our data demonstrate that salt marshes are significant habitats for carbon accumulation in the biosphere, acting as important but previously neglected carbon sinks. The remarkable combination of their high capacity for carbonsequestration but low carbon stock in salt marshes could reflect the past management approach to these habitats, which has resulted in significantly reduced areal extent. The "coastal squeeze" phenomenon affects salt marshes most

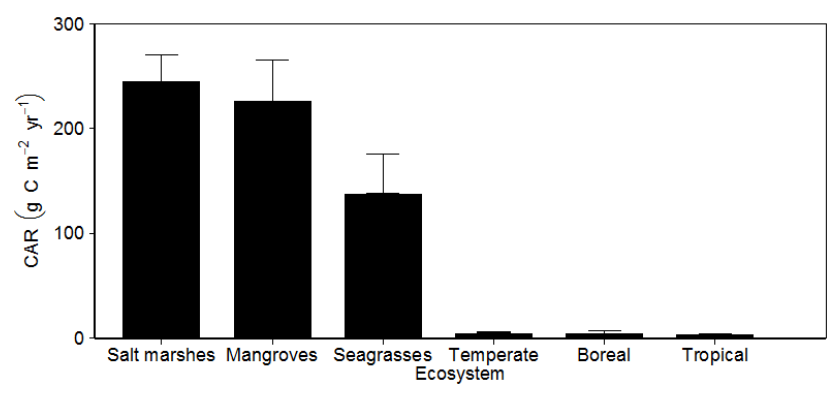

Figure 6. Average CAR $( \pm \mathrm{SE})$ in sediments and soils of major coastal and terrestrial forest ecosystems.

significantly and, if not managed urgently, will continue to erode the importance of salt marshes as potential carbon storages. Despite their high capacity of carbon accumulation, when compared with terrestrial forests, carbon buried in salt marshes, as part of "blue carbon", can be stable over longer timescales (millennia) (Duarte et al., 2005; McLeod et al., 2011) and decomposes at a lower rate (Reddy and DeLaune, 2004), while most forest carbon stocks are often eventually released to atmosphere during forest fires (Fourqurean et al., 2012).

However, this global estimate of CAR in salt marshes needs to be interpreted with caution, since the estimate is limited by the quality and quantity of available data. First, the reported global area of salt marshes is far from complete and has not covered all habitats of salt marsh halophytes. Second, there are some compromises made when making extrapolations from a limited database. For example, no CAR data is available for any African salt marshes and values from geographically or taxonomically proximal 
sources have to be used for estimating CAR for this region. Third, drivers such as local ocean currents may cause deviations in temperature from the latitudinal trend. The analysis was conducted as an attempt to address broad latitudinal patterns in CAR. Additionally, some carbon values were estimated from organic matter content according to the formula of Craft et al. (1991), which was based on soil samples from North Carolina (USA). This conversion factor can be variable. For example, another study converted soil carbon stock of salt marshes from soil organic matter with a factor of 0.55 based on widely sampled terrestrial soils (Ford et al., 2012). If the latter conversion factor was applied to our study, some carbon values would increase by $\sim 37.5 \%$. Last but not least, there is not sufficient information about detailed halophyte composition in the collated references, thereby hindering our attempt to conduct further fine-grained analyses beyond the genus level. Again, this study is meant to be a broad-scale analysis of the global pattern of CAR in salt marsh communities. As such, variations at a fine scale are not necessarily addressed. Accordingly, further studies will be needed to refine CAR of this study when more data are available from a more comprehensive coverage of halophyte habitats in the future.

\section{Conclusions}

With sediment CAR averaged at $244.7 \pm 26.1 \mathrm{~g} \mathrm{C} \mathrm{m}^{-2} \mathrm{yr}^{-1}$, our global estimate indicates that salt marshes rank among the most effective ecosystems in carbon sequestration. The highest CAR was in the northern Mediterranean, whereas the lowest CAR was in the Arctic. Regarding the five major halophyte genera, Spartina-dominated marshes have the highest CAR, whereas the CAR of Distichlis-dominated habitats is the lowest. Owing to the comparatively small areal extent of salt marshes, global carbon buried in salt marshes is approximately $10.2 \mathrm{Tg} \mathrm{Cyr}^{-1}$, which is far lower than those of other coastal ecosystems and terrestrial forest ecosystems. The accuracy of this estimate, however, is compromised by large data gaps in CAR for some regions, e.g., Africa, Australasia and Sino-Japan.

Our analysis suggests that the CAR of salt marshes changes with latitude, tidal range, halophyte genera and habitat elevation. CAR of salt marshes varied significantly at latitude intervals of $10^{\circ}$ from $28.4^{\circ} \mathrm{N}$ to $69.7^{\circ} \mathrm{N}$. These factors drive CAR variation through physical and biotic control on belowground biomass productivity, microbial decomposition and litter input. Furthermore, it is clear that the CAR of low marsh was higher than high marsh, whereas the capacity of carbon sequestration in mid-marsh was lower than that of high marsh. Further field studies and experiments are needed to investigate the underlying forces driving carbon sequestration with respect to marsh elevation.

The findings of this study confirm salt marshes as significant coastal hotspots in sequestering carbon. However, with an annual loss rate of 1-2\% between 1980 and 2000 (Duarte et al., 2008), and with loss continuing, similar to the mangroves (Kristensen et al., 2008), this trend seriously compromises the capacity of salt marshes for carbon storage, unless proper management and rehabilitation is implemented. There are significant data gaps in salt marsh CARs. Further research on CAR of salt marshes in South America and South Asia as well as inclusion of the full range of salt marsh halophytes is strongly recommended.

\section{The Supplement related to this article is available online at doi:10.5194/bg-11-5057-2014-supplement.}

Acknowledgements. We thank the handling editor and three reviewers for their constructive comments. Several researchers provided unpublished information about their studies covered in our survey: we thank particularly the contribution of D. Cahoon and A. Lawrence.

Edited by: J.-A. Subkehack

\section{References}

Adams, C. A., Andrews, J. E., and Jickells, T.: Nitrous oxide and methane fluxes vs. carbon, nitrogen and phosphorous burial in new intertidal and saltmarsh sediments, Sci. Total Environ., 434, 240-251, doi:10.1016/j.scitotenv.2011.11.058, 2012.

Adams, J. B. and Bate, G. C.: Ecological implications of tolerance of salinity and inundation by Spartina maritima, Aquat. Bot., 52, 183-191, doi:10.1016/0304-3770(95)00496-3, 1995.

Andersen, T., Svinth, S., and Pejrup, M.: Temporal variation of accumulation rates on a natural salt marsh in the 20th century - The impact of sea level rise and increased inundation frequency, Mar. Geol., 279, 178-187, 2011.

Andrews, J., Samways, G., and Shimmield, G.: Historical storage budgets of organic carbon, nutrient and contaminant elements in saltmarsh sediments: Biogeochemical context for managed realignment, Humber Estuary, UK, Sci. Total Environ., 405, 1-13, 2008.

Anisfeld, S. C., Tobin, M. J., and Benoit, G.: Sedimentation rates in flow-restricted and restored salt marshes in Long Island Sound, Estuaries, 22, 231-244, 1999.

Asner, G. P., Rudel, T. K., Aide, T. M., Defries, R., and Emerson, R.: A contemporary assessment of change in humid tropical forests, Conserv. Biol., 23, 1386-1395, 2009.

Batjes, N. H.: Total carbon and nitrogen in the soils of the world, Eur. J. Soil Sci., 47, 151-163, 1996.

Bird, M., Fifield, L., Chua, S., and Goh, B.: Calculating sediment compaction for radiocarbon dating of intertidal sediments, Radiocarbon, 46, 421-435, 2004.

Blum, L. K.: Spartina alterniflora root dynamics in a Virginia marsh, Mar. Ecol.-Prog. Ser., 102, 169-178, 1993.

Bryant, J. C. and Chabreck, R. H.: Effects of impoundment on vertical accretion of coastal marsh, Estuaries, 21, 416-422, 1998. 
Butler, C. and Weis, J.: Salt marshes: A Natural and Unnatural History, Rutgers University Press, 1-13, 2009.

Caçador, I., Costa, A., and Vale, C.: Nitrogen sequestration capacity of two salt marshes from the Tagus estuary, Hydrobiologia, 587, 137-145, 2007.

Cahoon, D. R. and Turner, R. E.: Accretion and canal impacts in a rapidly subsiding wetland II., Feldspar marker horizon technique, Estuaries, 12, 260-268, 1989.

Cahoon, D. R.: Recent accretion in two managed marsh impoundments in coastal Louisiana, Ecol. Appl., 4, 166-176, 1994.

Cahoon, D. R., Lynch, J. C., and Powell, A. N.: Marsh vertical accretion in a southern California estuary, USA, Estuar. Coast. Shelf S., 43, 19-32, 1996.

Cahoon, D. R.: Storms as agents of wetland elevation change: their impact on surface and subsurface sediment processes, Proceedings of the International Conference on Coastal Sediments 2003, Clearwater Beach, FL, USA, 18-23 May, 2003.

Cahoon, D. R., Perez, B. C., Segura, B. D., and Lynch, J. C.: Elevation trends and shrink-swell response of wetland soils to flooding and drying, Estuar. Coast. Shelf S., 91, 463-474, 2011.

Callaway, J. C., DeLaune, R. D., and Patrick, W. H.: Chernobyl ${ }^{137} \mathrm{Cs}$ used to determine sediment accretion rates at selected northern European coastal wetlands, Limnol. Oceanogr., 41, 444-450, 1996.

Callaway, J. C., DeLaune, R. D., and Patrick, W. H.: Sediment accretion rates from four coastal wetlands along the Gulf of Mexico, J. Coastal Res., 13, 181-191, 1997.

Callaway, J. C., Borgnis, E. L., Turner, R. E., and Milan, C. S.: Carbon sequestration and sediment accretion in San Francisco Bay tidal wetlands, Estuar. Coast., 35, 1163-1181, 2012.

Castro, P. C. O.: Assessing Key-Habitat Loss Due to Eutrophication in the Mondego and Mira Estuaries, Ph.D. Thesis, University of Coimbra, Portugal, 2005.

Chmura, G. L., Anisfeld, S. C., Cahoon, D. R., and Lynch, J. C.: Global carbon sequestration in tidal, saline wetland soils, Global Biogeochem. Cy., 17, 1111, doi:10.1029/2002GB001917, 2003.

Chmura, G. L. and Hung, G. A.: Controls on salt marsh accretion: A test in salt marshes of Eastern Canada, Estuaries, 27, 70-81, 2004.

Chmura, G. L., Kellman, L., and Guntenspergen, G. R.: The greenhouse gas flux and potential global warming feedbacks of a northern macrotidal and microtidal salt marsh, Environ. Res. Lett., 6, 1-6, 2011.

Connor, R. F., Chmura, G. L., and Beecher, C. B.: Carbon accumulation in Bay of Fundy salt marshes: Implications for restoration of reclaimed marshes, Global Biogeochem. Cy., 15, 943-954, doi:10.1029/2000gb001346, 2001

Craft, C., Seneca, E., and Broome, S.: Loss on ignition and Kjeldahl digestion for estimating organic carbon and total nitrogen in estuarine marsh soils: calibration with dry combustion, Estuaries, 14, 175-179, 1991.

Craft, C., Clough, J., Ehman, J., Joye, S., Park, R., Pennings, S., Guo, H., and Machmuller, M.: Forecasting the effects of accelerated sea-level rise on tidal marsh ecosystem services, Front. Ecol. Environ., 7, 73-78, 2008.

Craft, C. B., Seneca, E. D., and Broome, S. W.: Vertical accretion in microtidal regularly and irregularly flooded estuarine marshes, Estuar. Coast. Shelf S., 37, 371-386, 1993.
Curado, G., Rubio-Casal, A. E., Figueroa, E., Grewell, B. J., and Castillo, J. M.: Native plant restoration combats environmental change: development of carbon and nitrogen sequestration capacity using small cordgrass in European salt marshes, Environ. Monit. Assess., 185, 1-11, doi:10.1007/s10661-013-3185-4, 2013.

Day, J. W., Kemp, G. P., Reed, D. J., Cahoon, D. R., Boumans, R. M., Suhayda, J. M., and Gambrell, R.: Vegetation death and rapid loss of surface elevation in two contrasting Mississippi delta salt marshes: The role of sedimentation, autocompaction and sealevel rise, Ecol. Eng., 37, 229-240, 2011.

Dijkema, K. S.: Geography of salt marshes in Europe, Z. Geomorphol., 31, 489-499, 1987.

Donato, D. C., Kauffman, J. B., Murdiyarso, D., Kurnianto, S., Stidham, M., and Kanninen, M.: Mangroves among the most carbonrich forests in the tropics, Nat. Geosci., 4, 293-297, 2011.

Doody, J. P.: "Coastal squeeze" - an historical perspective, J. Coast. Conserv., 10, 129-138, 2004.

Duarte, C. M., Middelburg, J. J., and Caraco, N.: Major role of marine vegetation on the oceanic carbon cycle, Biogeosciences, 2 , 1-8, doi:10.5194/bg-2-1-2005, 2005.

Duarte, C. M., Dennison, W. C., Orth, R. J., and Carruthers, T. J. B.: The charisma of coastal ecosystems: Addressing the imbalance, Estuar. Coast., 31, 233-238, 2008.

Edwards, K. R., and Proffitt, C. E.: Comparison of wetland structural characteristics between created and natural salt marshes in southwest Louisiana, USA, Wetlands, 23, 344-356, 2003.

Elsey-Quirk, T., Seliskar, D. M., Sommerfield, C. K., and Gallagher, J. L.: Salt marsh carbon pool distribution in a MidAtlantic lagoon, USA: sea level rise implications, Wetlands, 31, 87-99, 2011.

Field, D. W., Reyer, A. J., Genovese, P. V., and Shearer, B. D.: Coastal wetlands of the United States: An accounting of a valuable national resource: a special NOAA 20th anniversary report, Strategic Assessment Branch, Ocean Assessment Division, National Ocean Service/National Oceanic and Atmospheric Administration, Washington DC, 1991.

Ford, H., Garbutt, A., Jones, L., and Jones, D. L.: Methane, carbon dioxide and nitrous oxide fluxes from a temperate salt marsh: grazing management does not alter Global Warming Potential, Estuar. Coast. Shelf S., 113, 182-191, doi:10.1016/j.ecss.2012.08.002, 2012.

Fourqurean, J. W., Duarte, C. M., Kennedy, H., Marba, N., Holmer, M., Mateo, M. A., Apostolaki, E. T., Kendrick, G. A., Krause-Jensen, D., McGlathery, K. J., and Serrano, O.: Seagrass ecosystems as a globally significant carbon stock, Nat. Geosci., 5, 505-509, 2012.

French, J. R. and Spencer, T.: Dynamics of sedimentation in a tidedominated backbarrier salt marsh, Norfolk, UK, Mar. Geol., 110, 315-331, 1993.

Gedan, K. B., Silliman, B. R., and Bertness, M. D.: Centuries of human-driven change in salt marsh ecosystems, Annu. Rev. Mar. Sci., 1, 117-141, 2009.

Giri, C., Ochieng, E., Tieszen, L. L., Zhu, Z., Singh, A., Loveland, T., Masek, J., and Duke, N.: Status and distribution of mangrove forests of the world using earth observation satellite data, Global. Ecol. Biogeogr., 20, 154-159, 2011.

Gonzalez-Alcaraz, M. N., Egea, C., Jimenez-Carceles, F. J., Parraga, I., Maria-Cervantes, A., Delgado, M. J., and Alvarez- 
Rogel, J.: Storage of organic carbon, nitrogen and phosphorus in the soil-plant system of Phragmites australis stands from a eutrophicated Mediterranean salt marsh, Geoderma, 185, 61-72, doi:10.1016/j.geoderma.2012.03.019, 2012.

Hanson, A. and Calkins, L.: Wetlands of the Maritime Provinces: revised documentation for the wetlands inventory, Environment Canada, Canadian Wildlife Service, Atlantic Region, 1996.

Hatton, R. S., DeLaune, R. D., and Patrick Jr, W.: Sedimentation, accretion, and subsidence in marshes of Barataria Basin, Louisiana, Limnol. Oceanogr., 28, 494-502, 1983.

Hensel, P. F., Day, J. W., and Pont, D.: Wetland vertical accretion and soil elevation change in the Rhone River delta, France: The importance of riverine flooding, J. Coastal Res., 15, 668-681, 1999.

Howe, A. J., Rodriguez, J. F., and Saco, P. M.: Surface evolution and carbon sequestration in disturbed and undisturbed wetland soils of the Hunter estuary, southeast Australia, Estuar. Coast. Shelf S., 84, 75-83, 2009.

Howes, B. L., Dacey, J. W. H., and Teal, J. M.: Annual carbon mineralization and belowground production of Spartina alterniflora in a New England salt marsh, Ecology, 66, 595-605, 1985.

Hussein, A. H., Rabenhorst, M. C., and Tucker, M. L.: Modeling of carbon sequestration in coastal marsh soils, Soil Sci. Soc. Am. J., 68, 1786-1795, 2004.

Ibañez, C., Curco, A., Day, J. W. J., and Prat, N.: Structure and productivity of microtidal Mediterranean coastal marshes., in: Concepts and Controversies in Tidal Marsh Ecology, edited by: Weinstein, M. P. and Kreeger, D. A., Kluwer Academic Publishers, Dordrecht, the Netherlands, 107-136, 2000.

Jensen, L. A., Schmidt, L. B., Hollesen, J., and Elberling, B.: Accumulation of soil organic carbon linked to Holocene sea level changes in west Greenland, Arct. Antarct. Alp. Res., 38, 378383, 2006

Johnson, B. J., Moore, K. A., Lehmann, C., Bohlen, C., and Brown, T. A.: Middle to late Holocene fluctuations of $\mathrm{C}_{3}$ and $\mathrm{C}_{4}$ vegetation in a Northern New England Salt Marsh, Sprague Marsh, Phippsburg Maine, Org. Geochem., 38, 394-403, 2007.

Kearney, M. S. and Stevenson, J. C.: Island land loss and marsh vertical accretion rate evidence for historical sea-level changes in Chesapeake Bay, J. Coastal Res., 7, 403-415, 1991.

Keller, J. K., Takagi, K. K., Brown, M. E., Stump, K. N., Takahashi, C. G., Joo, W., Au, K. L., Calhoun, C. C., Chundu, R. K., and Hokutan, K.: Soil organic carbon storage in restored salt marshes in Huntington Beach, California, Bull. Southern California Acad. Sci., 111, 153-161, 2012.

Kennedy, H., Beggins, J., Duarte, C. M., Fourqurean, J. W., Holmer, M., Marba, N., and Middelburg, J. J.: Seagrass sediments as a global carbon sink: isotopic constraints, Global Biogeochem. Cy., 24, 1-8, 2010.

Kirwan, M. L., Guntenspergen, G. R., and Morris, J. T.: Latitudinal trends in Spartina alterniflora productivity and the response of coastal marshes to global change, Global Change Biol., 15, 1982-1989, 2009.

Kirwan, M. L. and Guntenspergen, G. R.: Feedbacks between inundation, root production, and shoot growth in a rapidly submerging brackish marsh, J. Ecol., 100, 764-770, 2012.

Koch, E. W., Barbier, E. B., Silliman, B. R., Reed, D. J., Perillo, G. M. E., Hacker, S. D., Granek, E. F., Primavera, J. H., Muthiga, N., Polasky, S., Halpern, B. S., Kennedy, C. J., Kap- pel, C. V., and Wolanski, E.: Non-linearity in ecosystem services: temporal and spatial variability in coastal protection, Front. Ecol. Environ., 7, 29-37, 2009.

Kristensen, E., Bouillon, S., Dittmar, T., and Marchand, C.: Organic carbon dynamics in mangrove ecosystems: a review, Aquat. Bot., 89, 201-219, 2008.

Laffoley, D. and Grimsditch, G.: The Management of Natural Coastal Carbon Sinks, IUCN, Gland, Switzerland, 2009.

Lawrence, A., Baker, E., and Lovelock, C.: Optimising and managing coastal carbon: comparative sequestration and mitigation opportunities across Australia's landscapes and land uses, FRDC Report 2011/084, Fisheries Research and Development Corporation, 3, 2012.

Lee, S. Y.: Mangrove outwelling: a review, Hydrobiologia, 295, 203-212, 1995.

Loomis, M. J. and Craft, C. B.: Carbon sequestration and nutrient (nitrogen, phosphorus) accumulation in river-dominated tidal marshes, Georgia, USA, Soil Sci. Soc. Am. J., 74, 1028-1036, 2010.

Lovelock, C. E., Sorrell, B. K., Hancock, N., Hua, Q., and Swales, A.: Mangrove forest and soil development on a rapidly accreting shore in New Zealand, Ecosystems, 13, 437-451, 2010.

Mahaney, W. M., Smemo, K. A., and Gross, K. L.: Impacts of $\mathrm{C} 4$ grass introductions on soil carbon and nitrogen cycling in C3-dominated successional systems, Oecologia, 157, 295-305, 2008.

Markewich, H. W.: Carbon storage and late holocene chronostratigraphy of a Mississippi River deltaic marsh, St. Bernard Parish, Louisiana, US Geological Survey, Open-File Report 9836, 1998.

McCaffrey, R. J. and Thomson, J.: A record of the accumulation of sediment and trace metals in a Connecticut salt marsh, Adv. Geophys., 22, 165-236, 1980.

McLeod, E., Chmura, G. L., Bouillon, S., Salm, R., Bjork, M., Duarte, C. M., Lovelock, C. E., Schlesinger, W. H., and Silliman, B. R.: A blueprint for blue carbon: toward an improved understanding of the role of vegetated coastal habitats in sequestering $\mathrm{CO}_{2}$, Front. Ecol. Environ., 9, 552-560, 2011.

Mitsch, W., Mitsch, R., and Turner, R.: Wetlands of the Old and New Worlds: Ecology and Management, Elsevier, Amsterdam, Netherland, 169-179, 1994.

Mold, R. J.: Ecology of Halophytes, Academic Press Inc., New York, US, 3-13, 1974.

Murray, B. C., Pendleton, L., Jenkins, W. A., and Sifleet, S.: Green payments for blue carbon: Economic incentives for protecting threatened coastal habitats, Nicholas Institute for Environmental Policy Solutions, Report NI, 11, 04, 2011.

O'Callaghan, M.: Saltmarshes: a highly specialized environment, Custos, 18, 59-60, 1990.

Oenema, O. and Delaune, R. D.: Accretion rates in salt marshes in the Eastern Scheldt, south-west Netherlands, Estuar. Coast. Shelf S., 26, 379-394, 1988.

Orson, R. A., Warren, R. S., and Niering, W. A.: Interpreting sea level rise and rates of vertical marsh accretion in a southern New England tidal salt marsh, Estuar. Coast. Shelf S., 47, 419-429, 1998.

Ouyang, X. G., Shi, L., Yu, H. Y., Liu, Y. Q., Guo, F., and Wang, J.: Vertical accretion rate implicates sea level and climate change, 
2013 Beijing International Environmental Technology Conference, Beijing, China, 21-23 October, 2013.

Palomo, L. and Niell, F. X.: Primary production and nutrient budgets of Sarcocornia perennis ssp. alpini (Lag.) Castroviejo in the salt marsh of the Palmones River estuary (Southern Spain), Aquat. Bot., 91, 130-136, 2009.

Patrick, W. H. and Delaune, R. D.: Subsidence, accretion, and sealevel rise in south San Francisc Bay marshes, Limnol. Oceanogr., 35, 1389-1395, 1990.

Pierce, S. M.: Estimation of the non-seasonal production of Spartina maritima (Curtis) Fernald in a South African Estuary, Estuar. Coast. Shelf S., 16, 241-254, doi:10.1016/02727714(83)90143-9, 1983.

Polunin, N. V.: Aquatic Ecosystems: Trends and Global Prospects, Cambridge University Press, UK, 157-171, 2008.

Ranwell, D. S.: World resources of Spartina townsendii (sensu lato) and economic use of Spartina marshland, J. Appl. Ecol., 4, 239256, doi:10.2307/2401421, 1967.

Reddy, K. R. and DeLaune, R. D.: Biogeochemistry of Wetlands: Science and Applications, CRC Press, 2004.

Redfield, A. C.: Development of a New England salt marsh, Ecol. Monogr., 42, 201-237, 1972.

Roman, C. T., Peck, J. A., Allen, J. R., King, J. W., and Appleby, P. G.: Accretion of a New England (USA) salt marsh in response to inlet migration, storms, and sea-level rise, Estuar. Coast. Shelf S., 45, 717-727, 1997.

Rothman, E. and Bouchard, V.: Regulation of carbon processes by macrophyte species in a Great Lakes coastal wetland, Wetlands, 27, 1134-1143, 2007.

Rybczyk, J. and Cahoon, D.: Estimating the potential for submergence for two wetlands in the Mississippi River Delta, Estuaries, 25, 985-998, 2002.

Saint-Laurent, C., Lètourneau, G., and Jean, M.: Cartography of the marshes, marshes and herbaria watery along the St. Lawrence by airborne teledetection, Environment Canada-Area of Quebec, Conservation of the environment, Center Saint-Lawrence, Scientific report and Technical ST-61, 1996.
Saintilan, N., Rogers, K., Mazumder, D., and Woodroffe, C.: Allochthonous and autochthonous contributions to carbon accumulation and carbon store in southeastern Australian coastal wetlands, Estuar. Coast. Shelf S., 128, 84-92, 2013.

Sanders, C. J., Smoak, J. M., Naidu, A. S., Sanders, L. M., and Patchineelam, S. R.: Organic carbon burial in a mangrove forest, margin and intertidal mud flat, Estuar. Coast. Shelf S., 90, 168$172,2010$.

Schlesinger, W. H. and Bernhardt, E. S.: Biogeochemistry: an analysis of global change, Academic Press, Oxford, UK, 308-321, 2013.

Schuerch, M., Rapaglia, J., Liebetrau, V., Vafeidis, A., and Reise, K.: Salt marsh accretion and storm tide variation: an example from a barrier island in the North Sea, Estuar. Coast., 35, 486-500, 2012.

Sousa, A. I., Lillebo, A. I., Pardal, M. A., and Cacador, I.: The influence of Spartina maritima on carbon retention capacity in salt marshes from warm-temperate estuaries, Mar. Pollut. Bull., 61, 215-223, 2010a.

Sousa, A. I., Lillebo, A. I., Pardal, M. A., and Cacador, I.: Productivity and nutrient cycling in salt marshes: contribution to ecosystem health, Estuar. Coast. Shelf S., 87, 640-646, 2010b.

Spalding, M., Kainuma, M., and Collins, L.: World Atlas of Mangroves, Earthscan, London, UK, 47-52, 2010.

Turner, R. E.: Geographic variations in salt marsh macrophyte production: a review, Contrib. Mar. Sci., 20, 47-68, 1976.

Weinstein, M. P. and Kreeger, D. A.: Concepts and Controversies in Tidal Marsh Ecology, Springer, New York, US, 583-595, 2000.

Xiaonan, D., Xiaoke, W., Lu, F., and Zhiyun, O.: Primary evaluation of carbon sequestration potential of wetlands in China, Acta Ecol. Sin., 28, 463-469, 2008.

Yang, S.-L. and Chen, J.-Y.: Coatal salt marshes and mangrove swamps in China, Chin. J. Oceanol. Limn., 13, 318-324, 1995.

Zehetner, F.: Does organic carbon sequestration in volcanic soils offset volcanic $\mathrm{CO}_{2}$ emissions?, Quaternary Sci. Rev., 29, 13131316, 2010.

Zhou, J. L., Wu, Y., Kang, Q. S., and Zhang, J.: Spatial variations of carbon, nitrogen, phosphorous and sulfur in the salt marsh sediments of the Yangtze Estuary in China, Estuar. Coast. Shelf S., 71, 47-59, 2007. 